\title{
ANALISIS PEMILIHAN ATRIBUT PRODUK BARU UNTUK PERILAKU KEPUTUSAN PEMBELIAN KONSUMEN PADA PRODUK BIOKOS BOTU-LIKE SERIES
}

\author{
Hartiwi Prabowo"; Synthia Atas Sari²; Idris Gautama ${ }^{3}$
}

\begin{abstract}
Article was made to answer these several questions which are how is application marketing mix of new product PT Martina Berto, what is new product atribute the most dominate for customer and how is buying decided behavior Biokos BOTU-Like Series. The result of the research show that application of marketing mix of by PT Martina Berto is good, customers are satisfaction that service Biokos BOTU-LIKE Series so they will to buy again and new product attribute the most dominate is price attribute at price level Rp94.500,00.
\end{abstract}

Keywords: product developed, product attribute, buying decided behavior

ABSTRAK

Artikel bertujuan menjawab beberapa pertanyaan, yaitu bagaimana penerapan bauran pemasaran produk baru PT Martina Berto, apa atribut produk baru yang paling dominan bagi konsumen, dan bagaimana perilaku keputusan pembelian Biokos BOTULIKE Series. Hasil penelitian menunjukkan bahwa bauran pemasaran yang diterapkan PT. Martina Berto sudah baik, konsumen cukup puas terhadap kinerja Biokos BOTULIKE sehingga ingin melakukan pembelian ulang, dan atribut produk baru yang paling dominan adalah atribut harga pada level harga Rp94.500,00.

Kata Kunci: pengembangan produk, atribut produk, perilaku keputusan pembelian

\footnotetext{
1,2,3 Jurusan Manajemen, Fakultas Ekonomi, UBiNus, Jl. K.H. Syahdan No. 9, Kemanggisan/Palmerah, Jakarta Barat 11480 hartiwi2200@lecturer.binus.ac.id, synthia@binus.ac.id, igautama@binus.ac.id
} 


\section{PENDAHULUAN}

Menyadari kebutuhan konsumen akan penggunaan bahan alami dan kualitas yang tinggi dalam kosmetik mereka, PT Martha Tilaar yang merupakan salah satu pemimpin pasar produsen kosmetik dan perawatan kulit nasional mengembangkan produk baru yang dapat menjawab kebutuhan dan masalah wanita akan kulit. Sebagai perusahaan kosmetik lokal, Martha Tilaar memahami kebutuhan yang tepat bagi kulit wanita Indonesia dan mengembangkan kosmetik yang sesuai bagi kulit wanita Asia, khususnya Indonesia.

PT Martha Tilaar memiliki beberapa anak perusahaan dan brand, diantaranya PT Martina Berto dengan produknya Biokos yang merupakan produk perawatan kulit yang khusus dikembangkan untuk mengatasi masalah kulit bagi segmen usia 20, 30, dan 40 tahun ke atas. Oleh karena itu, dengan berpijak pada penggunaan bahan alami yang dipadukan dengan teknologi tinggi Martha Tilaar mengembangkan produk Biokos BOTU-LIKE Series yang terinspirasi dari efektivitas suntik Botox. BOTU-LIKE Series merupakan produk perawatan kulit alternatif dari suntik botox untuk mengatasi garis ekspresi permanen yang timbul di dahi, antara alis, garis senyum, dan sudut bibir. Pengembangan produk yang dilakukan oleh PT Martina Berto bertujuan untuk memperluas pangsa pasar yang ditunjukkan dengan peningkatan penjualan terhadap produk Biokos BOTU-LIKE Series. Diharapkan dengan adanya produk baru ini, akan dapat menarik lebih banyak konsumen wanita dengan segmen usia 40 tahun ke atas. Identifikasi masalah dalam penelitian adalah bagaimana PT Martina Berto menerapkan bauran pemasaran sehubungan dengan produk baru Biokos BOTU-LIKE SERIES? Bagaimana konsumen memilih atribut produk yang dominan untuk produk Biokos BOTU-LIKE Series? Bagaimana perilaku konsumen untuk pengambilan keputusan membeli produk baru Biokos?

Tujuan penelitian adalah untuk mengetahui penerapan bauran pemasaran oleh PT Martina Berto sehubungan dengan pengembangan produk baru; Untuk mengetahui bagaimana konsumen memilih atribut produk yang dominan untuk produk Biokos BOTU-LIKE Series; Untuk mengetahui pengambilan keputusan pembelian konsumen atas produk baru Biokos.

Penelitian ini bermanfaat, yaitu pertama, bagi perusahaan adalah perusahaan dapat mengembangkan bauran pemasaran yang sesuai bagi produk baru untuk memperluas pangsa pasar; Perusahaan dapat mengetahui atribut produk baru yang paling diinginkan konsumen; Perusahaan dapat mengetahui bagaimana perilaku konsumen dalam mengambil keputusan untuk membeli; Memberi pertimbangan bagi perusahaan dalam keputusan yang berhubungan dengan pengembangan produk baru di masa mendatang. Manfaat yang kedua, yaitu bagi penulis adalah dapat menambah wawasan dan pengetahuan terutama mengenai pengembangan produk baru. Manfaat ketiga, yaitu bagi dunia pendidikan adalah dapat menjadi bahan perbandingan dengan topik yang berkaitan dengan pengembangan produk baru dan menjadi bahan referensi bagi peneliti lain yang ingin mengembangkan topik ini 


\section{TINJAUAN PUSTAKA}

\section{Pengertian Pengembangan Produk Baru}

Menurut Alma (2004:139), "Pengembangan produk adalah semua kegiatan yang dilakukan oleh pabrikan atau produsen dalam menentukan dan mengembangkan produknya, memperbaiki produk lama, menambah produk baru atau jasa yang sudah ada, dan mengurangi biaya-biaya produksi dan biaya pembungkus." Menurut Ulrich dan Eppinger (2003:2), "Pengembangan produk adalah seperangkat aktivitas yang dimulai dari persepsi dari kesempatan pasar dan berakhir pada produksi, penjualan, dan pengangkutan produk."

\section{Kategori Produk Baru}

Kantor konsultan Booz, Allen \& Hamilton (Kotler, 2004:374) mengidentifikasi enam kategori produk baru. Pertama, produk baru bagi dunia. Produk baru yang menciptakan suatu pasar yang sama sekali baru. Kategori itu menyumbang sebanyak $10 \%$ produk baru. Kedua, lini produk baru. Produk baru yang memungkinkan perusahaan untuk memasuki pasar yang telah mapan untuk pertama kalinya. Menyumbang sekitar $20 \%$ produk baru. Ketiga, tambahan pada lini produk yang telah ada. Produk baru yang melengkapi suatu lini produk perusahaan yang telah mantap (ukuran, kemasan, rasa, dan lain-lain). Terdapat sekitar $26 \%$ dari total produk baru yang beredar di pasar. Keempat, perbaikan dan revisi produk yang telah ada. Produk baru yang memberikan kinerja yang lebih baik atau nilai yang dianggap lebih hebat dan menggantikan produk yang telah ada. Menyumbang 26\% dari total produk baru. Kelima, penentuan kembali posisi. Produk yang telah ada diarahkan ke pasar atau segmen pasar baru. Terdapat 7\% kategori produk baru ini. Keenam, pengurangan biaya. Produk baru yang menyediakan kinerja serupa dengan harga yang lebih murah. Menyumbang $11 \%$ produk baru di pasar.

\section{Delapan Tahap Proses Pengembangan Produk}

Menurut Kotler (2004:382-403), terdapat delapan tahap proses pengembangan yaitu lahirnya gagasan; Penyaringan gagasan; Pengembangan dan pengujian konsep; Pengembangan strategi pemasaran; Analisis Bisnis; Pengembangan produk; Pengujian pasar; Komersialisasi.

\section{Perilaku Konsumen}

Menurut Schiffman dan Kanuk (2004:8), "Perilaku konsumen didefinisikan sebagai perilaku yang diperlihatkan konsumen dalam mencari, membeli, menggunakan, mengevaluasi, dan menghabiskan produk dan jasa yang mereka harapkan akan memuaskan kebutuhan mereka." Perilaku konsumen pada hakikatnya untuk memahami "why do consumer do what they do." Dapat disimpulkan bahwa perilaku konsumen 
adalah semua kegiatan, tindakan, serta proses psikologis yang mendorong tindakan tersebut pada saat sebelum membeli, ketika membeli, menggunakan, menghabiskan produk, dan jasa setelah melakukan hal tersebut atau kegiatan mengevaluasi (Sumarwan, 2004:26).

\section{Pengambilan Keputusan Konsumen}

Menurut Peter dan Olson (2000:162-163), "Pengambilan keputusan pembelian konsumen adalah proses pengintegrasian yang mengkombinasikan pengetahuan untuk mengevaluasi dua atau lebih perilaku alternatif dan memilih salah satu diantaranya.

Tabel 1 Model Perilaku Pembeli

\begin{tabular}{|c|c|c|c|c|}
\hline $\begin{array}{l}\text { Rangsangan } \\
\text { pemasaran }\end{array}$ & $\begin{array}{l}\text { Rangsangan } \\
\text { Lain }\end{array}$ & $\begin{array}{l}\text { Ciri-ciri } \\
\text { pembeli }\end{array}$ & $\begin{array}{l}\text { Proses keputusan } \\
\text { Pembelian }\end{array}$ & $\begin{array}{l}\text { Keputusan } \\
\text { Pembeli } \\
\end{array}$ \\
\hline \multirow{3}{*}{$\begin{array}{l}\text { Produk } \\
\text { Harga } \\
\text { Saluran } \\
\text { pemasaran }\end{array}$} & \multirow{2}{*}{$\begin{array}{l}\text { Ekonomi } \\
\text { Teknologi }\end{array}$} & Budaya & Pemahaman masalah & \multirow{5}{*}{$\begin{array}{l}\text { Pemilihan produk } \\
\text { Pemilihan merek } \\
\text { Pemilihan saluran } \\
\text { pembelian } \\
\text { Pemilihan waktu } \\
\text { pembelian }\end{array}$} \\
\hline & & Sosial & Pencarian informasi & \\
\hline & & & & \\
\hline Promosi & Budaya & psikologi & keputusan pembelian & \\
\hline & & & Perilaku pasca pembelian & \\
\hline
\end{tabular}

Sumber: Kotler dan Armstrong (2001:196)

\section{Pengambilan Keputusan Pembelian Sebagai Pemecahan Masalah}

Asumsi dasar dari pengambilan keputusan sebagai pemecahan masalah adalah konsumen memiliki sasaran (konsekuensi yang diinginkan atau nilai dalam rantai akhir) yang ingin dicapai. Pemecahan masalah konsumen sebenarnya adalah suatu aliran tindakan timbal balik yang berkesinambungan diantara faktor lingkungan, proses kognitif dan afektif, serta tindakan (Peter dan Olson, 2000:164).

\section{Tahap Pemecahan Masalah Konsumen}

Perusahaan yang cerdik melakukan riset atas proses keputusan pembelian kategori produk mereka. Mereka menanyai konsumen kapan mereka pertama kali mengenal kategori dan merek produk tersebut, serta seperti apa keyakinan merek mereka, seberapa besar mereka terlibat dengan produk yang bersangkutan, bagaimana mereka melakukan pemilihan merek, dan seberapa puas mereka setelah pembelian (Kotler, 2004:204). 


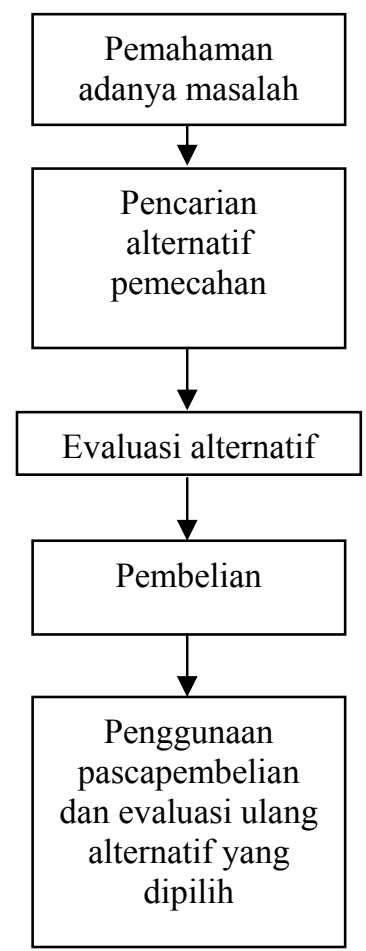

Sumber: Peter dan Olson (2000:165)

Gambar 1 Proses Pengambilan Keputusan

\section{Proses Penerimaan Konsumen terhadap Produk Baru}

Menurut Rogers (Kotler dan Armstrong, 2001:229), "Proses adopsi adalah proses mental yang dilalui seseorang, mulai dari pengenalan pertamanya dengan suatu inovasi sampai pada penerimaan/adopsi final," dan adopsi sebagai keputusan yang diambil seseorang untuk menjadi pengguna reguler sebuah produk.

\section{Tahap Proses Adopsi}

Konsumen melalui lima tahap proses adopsi sebuah produk baru (Kotler, 2004:405), yaitu Kesadaran (awareness); Tertarik (interest); Evaluasi (evaluation); Mencoba (trial); Adopsi (adoption). 


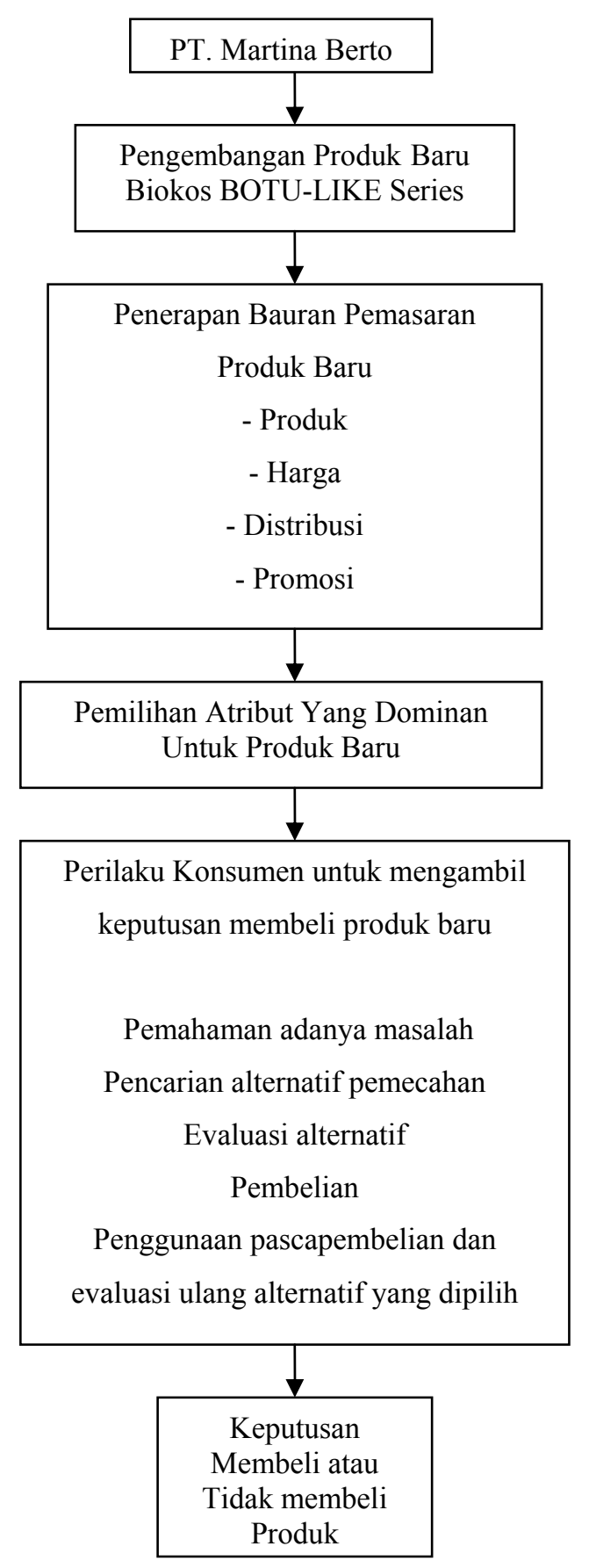

Gambar 2 Kerangka Berpikir 


\section{METODE PENELITIAN}

Tabel 2 Desain Penelitian

\begin{tabular}{cccc}
\hline & & \multicolumn{2}{c}{ Desain Penelitian } \\
\hline $\begin{array}{c}\text { Tujuan } \\
\text { Penelitian }\end{array}$ & $\begin{array}{c}\text { Jenis } \\
\text { Penelitian }\end{array}$ & Unit Analisis & Time Horizon \\
\hline Tujuan-1 & Deskriptif & Organisasi - PT. Martina Berto & Cross Sectional \\
Tujuan-2 & Deskriptif & Individu - Konsumen dan non pengguna Biokos & Cross Sectional \\
Tujuan-3 & Deskriptif & Individu - Konsumen dan non pengguna Biokos & Cross Sectional \\
\hline
\end{tabular}

Tabel 3 Operasionalisasi Variabel Bauran Pemasaran

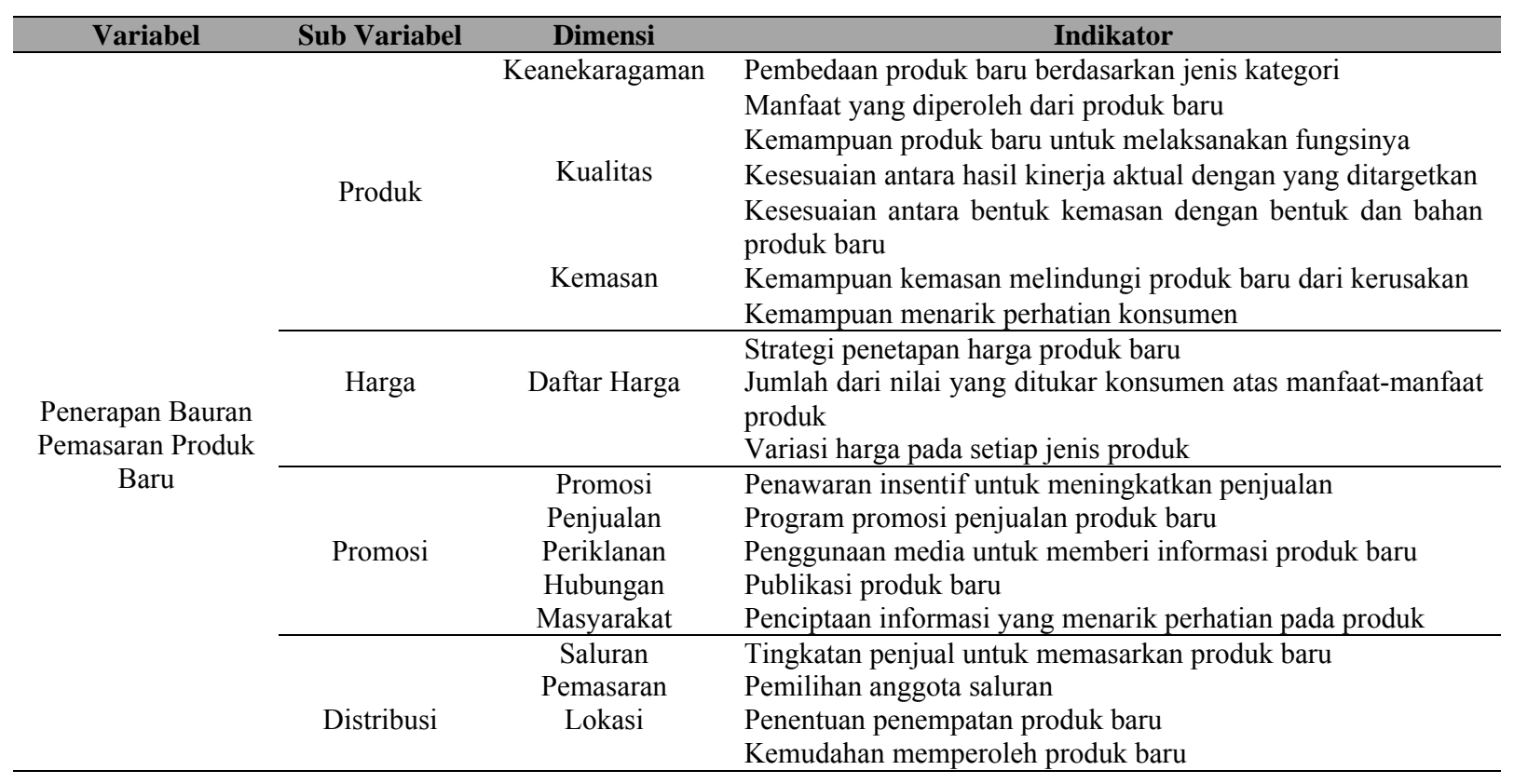

Sumber: Kotler dan Armstrong (2001) 
Tabel 4 Operasionalisasi Variabel Perilaku Pengambilan Keputusan Pembelian

\begin{tabular}{|c|c|c|c|}
\hline Variabel & Sub Variabel & Dimensi & Indikator \\
\hline \multirow{5}{*}{$\begin{array}{l}\text { Pengambilan } \\
\text { Keputusan } \\
\text { Pembelian } \\
\text { Konsumen }\end{array}$} & $\begin{array}{l}\text { Pemahaman } \\
\text { adanya masalah }\end{array}$ & $\begin{array}{l}\text { Perbedaan antara keadaan nyata dengan } \\
\text { keadaan yang diinginkan }\end{array}$ & Pengenalan masalah kulit \\
\hline & $\begin{array}{l}\text { Pencarian } \\
\text { alternatif } \\
\text { pemecahan }\end{array}$ & $\begin{array}{l}\text { Pencarian informasi yang berkaitan } \\
\text { dengan kebutuhan itu }\end{array}$ & $\begin{array}{l}\text { Cara mengatasi masalah } \\
\text { Produk yang digunakan untuk } \\
\text { perawatan kulit } \\
\text { Pengenalan terhadap produk } \\
\text { baru } \\
\text { Sumber informasi produk baru }\end{array}$ \\
\hline & Evaluasi alternatif & $\begin{array}{l}\text { Penggunaan informasi } \quad \text { untuk } \\
\text { mengevaluasi dan memilih alternatif } \\
\text { pilihan }\end{array}$ & $\begin{array}{l}\text { Atribut yang dipertimbangkan } \\
\text { Keunggulan produk baru } \\
\text { terhadap produk sejenis } \\
\text { Alasan penggunaan } \\
\text { Kepercayaan terhadap manfaat } \\
\text { produk baru }\end{array}$ \\
\hline & Pembelian & $\begin{array}{l}\text { Keputusan konsumen untuk membeli } \\
\text { merek yang telah dipilih }\end{array}$ & Keinginan membeli \\
\hline & $\begin{array}{l}\text { Penggunaan } \\
\text { pascapembelian } \\
\text { dan evaluasi ulang } \\
\text { alternatif yang } \\
\text { dipilih }\end{array}$ & $\begin{array}{l}\text { Penggunaan produk } \\
\text { Evaluasi antara harapan dan kinerja yang } \\
\text { dirasakan } \\
\text { Tanggapan konsumen terhadap atribut } \\
\text { produk }\end{array}$ & $\begin{array}{l}\text { Rekomendasi produk baru pada } \\
\text { orang lain } \\
\text { Kesesuaian kinerja dengan } \\
\text { harapan } \\
\text { Tanggapan terhadap kualitas } \\
\text { Tanggapan terhadap harga } \\
\text { Tanggapan terhadap Komposisi }\end{array}$ \\
\hline
\end{tabular}

Sumber: Peter dan Olson, Kotler dan Armstrong (2001)

\section{Teknik Pengumpulan Data}

Penulis melakukan pengumpulan data menggunakan metode pengumpulan data, yaitu pertama, Interview (Wawancara). Penulis melakukan wawancara langsung kepada marketing manager PT Martina Berto untuk mengetahui penerapan bauran pemasaran pada produk Biokos BOTU-LIKE. Kedua, Kuesioner (Angket). Kuesioner berupa daftar pertanyaan tertutup berbentuk pertanyaan multichotomous yang diajukan pada responden yaitu konsumen dan non pengguna Biokos untuk mengetahui preferensi terhadap atribut produk Biokos dan perilaku pengambilan keputusan pembelian produk Biokos.

\section{Teknik Pengambilan Sampel}

Prosedur pengambilan sampel menggunakan non-probability sampling dengan metode aksidental sampling. Pengumpulan data diambil dari kuesioner yang dibagikan pada konsumen dan non-konsumen di Puri Ayu dan pedagang retail, seperti Carrefour dan toko besar. 


\section{Teknik Pengolahan Sampel}

Teknik pengolahan sampel yang digunakan dalam penelitian ini adalah dengan rumus untuk menetapkan sampel yang populasinya tidak diketahui atau tidak terbatas. Berdasarkan rumus Cooper dan Schindler (2006:436) maka sampel yang diambil adalah 100 orang.

\section{Metode Analisis}

Tabel 5 Metode Analisis

\begin{tabular}{ccc}
\hline \multirow{2}{*}{ Tujuan Penelitian } & \multicolumn{2}{c}{ Metode Analisis } \\
\cline { 2 - 3 } & Metode & Alat analisis \\
\hline Tujuan-1 & Deskriptif survey & Wawancara \\
Tujuan-2 & Deskriptif survey & Statistik Deskriptif - Conjoint Analysis \\
Tujuan-3 & Deskriptif survey & Statistik Deskriptif - Distribusi Frekuensi \\
\hline
\end{tabular}

\section{Uji Validitas}

Pengujian validitas kuesioner ini menggunakan one shot method (internal consistency). Pengujian validitas ini dilakukan pada 30 responden.

\section{Uji Reliabilitas}

Uji reliabitas dilakukan dengan program SPSS For Windows dengan statistik Cronbach Alpha.

\section{Conjoint Analysis (Analisis Gabungan)}

Langkah pengerjaan analisis konjoin adalah sebagai berikut. Pertama, pada penelitian ini terdapat tiga atribut yang diukur (harga, manfaat, dan komposisi) maka akan ada 8 kasus (konsep produk) untuk dihitung atribut mana yang dominan. Kedua, diasumsikan bahwa responden merangking setiap konsep produk dengan skor 1 hingga 8 dan 1 menunjukkan tingkatan tertinggi dari preferen. Ketiga, setelah mengumpulkan data responden, langkah selanjutnya adalah memberi kode data pada cara yang sesuai untuk memperkirakan utilitas menggunakan mircosoft Excel. Keempat, prosedur yang dinamakan dummy coding akan dilakukan pada variabel independen (karakteristik produk). Kelima, masukkan dummy coding untuk semua hasil atribut kolom array.

Setelah didapat hasil utilitas tiap individu, utilitas tersebut akan dihitung secara agregat untuk memperkirakan preferensi terhadap atribut produk keseluruhan responden. Output akhir tersebut dapat digunakan untuk mengukur atribut mana yang paling dominan yang harus dimiliki oleh produk. 


\section{Analisis Regresi Berganda Dengan Dummy}

Model persamaan analisis konjoin dirumuskan secara matematis sebagai berikut. $Y=\alpha+\beta_{1} X_{1}+\beta_{2} X_{2}+\beta_{3} X_{3}+\varepsilon$

Dan: $\mathrm{Y}=$ Preferensi responden terhadap konsep produk, $\alpha=$ Konstanta atau intercept, $\beta=$ Beta weights (part-worth utilities) untuk atribut $\mathrm{X}=$ variabel dummy yang mewakili atribut produk $\varepsilon=$ Faktor eror

Pada model formulasi ini, koefisien untuk tingkat reference sama dengan 0. Cara penyelesaian memperkecil jumlah kuadrat error seluruh observasi. Standar error dari koefisien regresi (beta) menunjukkan seberapa tepat kita dapat memperkirakan koefisien itu dengan desain ini. Standar error yang lebih rendah, lebih baik.

\section{HASIL DAN PEMBAHASAN}

\section{Penerapan Bauran Pemasaran}

\section{Produk}

PT Martina Berto menerapkan beberapa strategi untuk mendukung citra produk sebagai produk perawatan kulit untuk kerut wajah yang mudah diaplikasikan dan menggunakan bahan alami yang dapat dikonsumsi oleh konsumen menengah atas dan menengah bawah.

\section{Keanekaragaman Produk}

Produk Biokos BOTU-LIKE SERIES terdiri dari tiga jenis. Pertama, Anti Wrinkle Intensive Correcting Serum yang merupakan serum dengan kandungan BOTULIKE Complex ${ }^{\mathrm{TM}}$ berkonsentrasi tinggi yang bekerja secara sinergis mengurangi garis ekspresi dan kerut serta membantu meningkatkan kekencangan kulit. Kedua, Anti Wrinkle Protective Day Treatment, merupakan pelembab wajah dengan kandungan BOTU-LIKE Complex ${ }^{\mathrm{TM}}$ yang secara terus menerus bekerja untuk menjaga kondisi kulit sekaligus mengurangi garis ekspresi yang nyata. Kandungan anti oksidan dan SPF 15-nya memberikan perlindungan lebih pada kulit dari pengaruh buruk lingkungan dan sinar ultra violet. Kulit wajah pun tetap sehat sepanjang hari dan tampak lebih muda. Ketiga, Anti Wrinkle Overnight Treatment merupakan krim malam dengan kandungan BOTU-LIKE Complex ${ }^{\mathrm{TM}}$ yang bekerja dengan efektif sepanjang malam untuk mengurangi kerut dan garis ekspresi yang nyata. Jenis produk yang ditawarkan terdiri dari tiga jenis. Hal itu dilakukan agar konsumen tidak perlu membeli satu set produk perawatan kulit yang kurang praktis dan harganya mahal. Produk berupa serum, day cream, dan night cream konsumen dapat diaplikasikan pada seluruh bagian wajah dan dapat mengatasi seluruh masalah kerutan wajah. 


\section{Kualitas}

Sebelum meluncurkan produk Biokos BOTU-LIKE ke pasar, PT Martina Berto mengadakan pengujian kualitas produk terlebih dahulu.

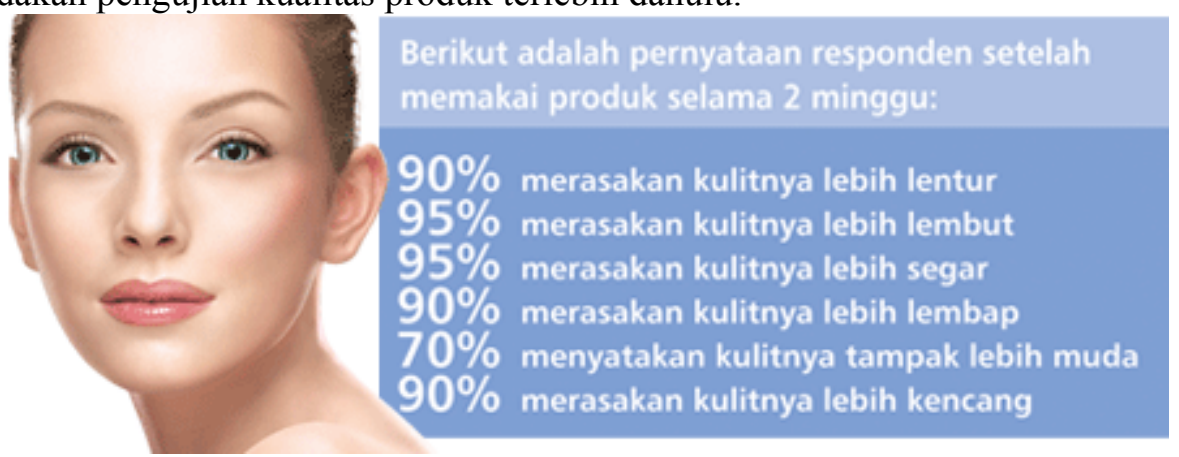

Sumber: PT Martina Berto (Website)

Gambar 3 Pernyataan Responden Setelah Memakai Produk

Produk Biokos BOTU-LIKE Series telah melalui uji keamanan dan uji manfaat yang dilakukan pada lebih dari 100 responden wanita di bawah pengawasan dokter ahli kulit sehingga tidak menyebabkan iritasi maupun alergi pada kulit hingga 96\%.

\section{Kemasan}

Kemasan Biokos BOTU-LIKE Series dibuat berwarna hijau untuk mendukung konsep citra produk, yaitu sebagai produk perawatan kulit untuk mengatasi kerutan kulit yang komposisinya menggunakan bahan alami. Untuk bahan baku kemasan, dibuat dari plastik agar konsumen lebih praktis menggunakan produk dan terhindar dari kerusakan kemasan akibat terjatuh.

\section{Harga}

Dalam menetapkan harga produk, PT Martina Berto menggunakan strategi penetapan harga penetrasi pasar.

Tabel 6 Daftar Harga Produk BOTU-LIKE Series

\begin{tabular}{cc}
\hline Jenis Produk & Harga \\
\hline Anti Wrinkle Intensive Correcting Serum & Rp 124.500 \\
Anti Wrinkle Protective Day Treatment & $\mathrm{Rp} \mathrm{94.500}$ \\
Anti Wrinkle Overnight Treatment & $\mathrm{Rp} \mathrm{94.500}$ \\
\hline
\end{tabular}

Sumber: PT Martina Berto 


\section{Promosi}

\section{Promosi Penjualan}

PT Martina Berto menyelenggarakan acara Launch Gathering pada tanggal 17 April 2006 untuk meluncurkan produk barunya, yaitu Biokos BOTU-LIKE Series yang diadakan di Crowne Plaza Hotel, Jl. Jendral Gatot Subroto, Jakarta. Dalam acara tersebut disediakan BOTU-LIKE Series limited edition dengan kemasan eksklusif. Kemasan limited edition tersebut bertujuan untuk mempromosikan uji coba awal terhadap produk baru. Sebagai puncak acara, undangan diberikan penawaran khusus yang sangat menarik, seperti diskon, voucher, dan lain-lain.

\section{Periklanan}

Untuk mempromosikan Biokos BOTU-LIKE, PT Martina Berto menggunakan iklan informatif dengan memasang iklan di koran, majalah, maupun tabloid, terutama yang memiliki sasaran pembaca wanita. Selain itu, dicetak juga brosur yang berisi penjelasan mengenai komposisi, manfaat, keunggulan produk Biokos BOTU-LIKE dibanding produk sejenis, dan cara pengaplikasan produk.

\section{Hubungan Masyarakat}

Bagian pemasaran PT Martha Tilaar mengadakan sejumlah aktivitas pemasaran berupa acara launching dan roadshow ke-5 kota besar di Indonesia. Selain acara launching dan roadshow, diadakan juga festival dan seminar untuk mempublikasikan Biokos BOTU-LIKE pada masyarakat. Pada tanggal 8-10 September 2006 Martha Tilaar Group mengadakan acara Martha Tilaar Beauty Innovation Festival 2006 yang diadakan di Mal Kelapa Gading Jakarta. Rangkaian acara Martha Tilaar Beauty Innovation Festival 2006 ini diliput oleh Metro TV dan harian Kompas. PT Martina Berto dengan produknya Biokos BOTU-LIKE juga sering menjadi sponsor dalam acara yang berhubungan dengan fashion dan kecantikan di beberapa stasiun TV dan radio, terutama radio yang basis pendengarnya adalah wanita, contohnya Female Radio.

\section{Distribusi}

Untuk memasarkan produknya, PT Martina Berto bekerja sama dengan PT Sari Ayu Indonesia selaku distributor produk Martha Tilaar untuk mendistribusikan Biokos BOTU-LIKE SERIES pada toko kosmetik, departemen store, supermarket, dan hypermarket, serta outlet milik PT Martha Tilaar sendiri. 


\section{Lokasi}

Produk Biokos, khususnya BOTU-LIKE SERIES telah tersedia pada outlet, baik pada outlet khusus produk Martha Tilaar maupun pada Mal dan Departemen Store di Jakarta, Surabaya, Medan, Lampung, Palembang, Bengkulu, Magelang, Solo, Makasar, Banjarmasin, Cirebon, Yogyakarta, Semarang, Denpasar, Pekanbaru, Bandung, Salatiga, Malang, dan Pekalongan.

\section{Hasil Kuesioner Analisis Konjoin}

Tabel 7 Format Pernyataan Analisis Konjoin

\begin{tabular}{|c|c|c|c|}
\hline & & & ripsi \\
\hline & Harga & Manfaat & Komposisi \\
\hline 1 & Rp94,500 & $\begin{array}{l}\text { Mengurangi kerutan dan } \\
\text { menghaluskan kulit }\end{array}$ & $\begin{array}{c}\text { Kandungan bahan alami dari tanaman dan akar- } \\
\text { akaran yang aman bagi kulit }\end{array}$ \\
\hline 2 & Rp94,500 & $\begin{array}{l}\text { Mengurangi kerutan dan } \\
\text { menghaluskan kulit }\end{array}$ & $\begin{array}{c}\text { Kandungan chamomile bahan anti iritasi dan alergi } \\
\text { (hypo-allergenic) }\end{array}$ \\
\hline 3 & Rp94,500 & $\begin{array}{l}\text { Mengencangkan dan } \\
\text { melembabkan kulit }\end{array}$ & $\begin{array}{l}\text { Kandungan bahan alami dari tanaman dan akar- } \\
\text { akaran yang aman bagi kulit }\end{array}$ \\
\hline 4 & Rp94,500 & $\begin{array}{l}\text { Mengencangkan dan } \\
\text { melembabkan kulit }\end{array}$ & $\begin{array}{c}\text { Kandungan chamomile bahan anti iritasi dan alergi } \\
\text { (hypo-allergenic) }\end{array}$ \\
\hline 5 & Rp124,500 & $\begin{array}{l}\text { Mengurangi kerutan dan } \\
\text { menghaluskan kulit }\end{array}$ & $\begin{array}{c}\text { Kandungan bahan alami dari tanaman dan akar- } \\
\text { akaran yang aman bagi kulit }\end{array}$ \\
\hline 6 & Rp124,500 & $\begin{array}{l}\text { Mengurangi kerutan dan } \\
\text { menghaluskan kulit }\end{array}$ & $\begin{array}{c}\text { Kandungan chamomile bahan anti iritasi dan alergi } \\
\text { (hypo-allergenic) }\end{array}$ \\
\hline 7 & Rp124,500 & $\begin{array}{l}\text { Mengencangkan dan } \\
\text { melembabkan kulit }\end{array}$ & $\begin{array}{l}\text { Kandungan bahan alami dari tanaman dan akar- } \\
\text { akaran yang aman bagi kulit }\end{array}$ \\
\hline 8 & Rp124,500 & $\begin{array}{l}\text { Mengencangkan dan } \\
\text { melembabkan kulit }\end{array}$ & $\begin{array}{c}\text { Kandungan chamomile bahan anti iritasi dan alergi } \\
\text { (hypo-allergenic) }\end{array}$ \\
\hline
\end{tabular}

Sumber: Brosur Produk Biokos BOTU-LIKE Series dan PT Martina Berto

Dari total 100 respoden yang menjawab menyatakan bahwa harga memiliki tingkat kepentingan tertinggi, yaitu sebesar $43.42 \%$. Hal itu berarti harga merupakan atribut paling penting yang mempengaruhi preferensi konsumen dan proses evaluasi pengambilan keputusan pembelian konsumen terhadap produk Biokos BOTU-LIKE. Utilitas harga pada level Rp 94,500 sebesar 0.243 menunjukkan bahwa konsumen lebih memilih membeli produk day cream atau night cream Biokos BOTU-LIKE Series yang harganya Rp94.500,00 dibandingkan membeli serum yang harganya Rp124.500,00 yang ditunjukkan dengan utilitas sebesar -0.243 .

Atribut lain yang mempengaruhi preferensi konsumen adalah atribut manfaat produk dengan tingkat kepentingan relatif sebesar $31.22 \%$. Tingkat utilitas sebesar 0.202 menunjukkan bahwa manfaat produk untuk mengencangkan dan melembabkan kulit lebih disukai dibandingkan mengurangi kerutan dan menghaluskan kulit yang ditunjukkan oleh tingkat utilitas sebesar -0.202 . 
Atribut komposisi memiliki tingkat kepentingan relatif yang paling rendah, yaitu sebesar $25.22 \%$ yang berarti konsumen tidak terlalu mempermasalahkan komposisi yang terkandung dalam Biokos BOTU-LIKE. Komposisi produk dari bahan Chamomile extract yang dapat mengurangi iritasi dan alergi memiliki tingkat utilitas sebesar 0.124 yang artinya kandungan bahan anti alergi dan anti iritasi lebih disukai dibanding atribut komposisi dengan kandungan bahan alami yang tingkat utilitasnya sebesar -0.124 .

Preferensi seluruh konsumen (tingkat agregat) menyatakan bahwa kombinasi level atribut Biokos BOTU-LIKE yang paling disukai adalah harga produk pada level Rp94.500,00 dan manfaat produk untuk megencangkan dan melembabkan kulit yang terdapat pada day cream dan night cream. Untuk atribut komposisi, level atribut yang disukai adalah bahan anti alergi dan anti iritasi. Hal itu berarti bahwa untuk level harga Rp124.500,00, manfaat untuk mengencangkan dan melembabkan kulit dan komposisi produk dari bahan alami merupakan kombinasi level atribut yang paling tidak disukai konsumen.

\section{Hasil Kuesioner Perilaku Pengambilan Keputusan Pembelian}

Dari hasil survei perilaku pengambilan keputusan pembelian, diketahui mayoritas responden yang mengunjungi outlet produk Biokos BOTU-LIKE adalah wanita dengan rentang umur antara 31 - 40 tahun dan memiliki profesi sebagai karyawan yang berpenghasilan di bawah Rp2.000.000,00.

\section{Pemahaman Adanya Masalah}

\section{Pengalaman Masalah Kerutan}

Dari 100 responden, sebanyak 58 responden (58\%) sedang mengalami masalah kerutan pada kulit dan sebanyak 42 responden $(42 \%)$ tidak pernah mengalami masalah kerutan pada kulit.

\section{Pencarian Alternatif Pemecahan}

\section{Cara Terbaik Mengatasi Kerutan}

Hasilnya, mayoritas responden, yaitu 55 orang (55\%) menganggap cara terbaik mengatasi kerutan adalah menggunakan krim perawatan kulit. 31 responden (31\%) menganggap masalah kerutan pada kulit lebih baik diatasi dengan suntik botox sedangkan sebanyak 14 orang menganggap lebih baik diatasi dengan operasi plastik.

\section{Produk Perawatan Kulit yang Biasa Digunakan}

Hasilnya, sebanyak 47 responden (47\%) menggunakan Biokos, yang menggunakan Sariayu berjumlah 29 responden (29\%). Sisanya, sebanyak 24 responden (24\%) menggunakan produk lain seperti Ponds, Biore, Oriflame, Bless, dan yang lainnya. 


\section{Pengenalan Produk Biokos BOTU-LIKE Series}

Dari 100 responden, terdapat 18 orang (18\%) yang tidak mengenal produk Biokos BOTU-LIKE. Sebanyak 45 responden (45\%) baru mengenal produk Biokos BOTU-LIKE sedangkan sisanya sebanyak 27 responden $(27 \%)$ telah sangat mengenal produk Biokos BOTU-LIKE

\section{Sumber Informasi Produk}

Dari total responden, sebanyak 72 orang yang sangat mengenal dan baru mengenal Biokos BOTU-LIKE, mayoritas responden memperoleh informasi mengenai Biokos BOTU-LIKE dari promosi sebanyak 39 orang (54.2\%). Sebanyak 24 responden (33.33\%) memperoleh informasi dari iklan media dan 9 responden memperoleh informasi dari word of mouth.

\section{Evaluasi Alternatif}

\section{Atribut Produk yang Dipertimbangkan}

Mayoritas responden, yaitu 54 orang (54\%) menyatakan bahwa harga adalah atribut yang mereka paling pertimbangkan dalam memilih produk perawatan kulit. Yang memilih kualitas sebagai atribut yang dipertimbangkan sebanyak 26 responden (26\%). Sisanya, 20 responden $(20 \%)$ memilih komposisi sebagai atribut yang dipertimbangkan dalam memilih produk perawatan kulit.

\section{Apakah Biokos BOTU-LIKE Lebih Unggul Dibanding Produk Sejenis}

Hasilnya, sebanyak 48 responden (48\%) menjawab setuju bahwa Biokos BOTULIKE Series lebih unggul dari dari produk sejenis, yang menyatakan tidak setuju akan keunggulan Biokos BOTU-LIKE dibanding produk lain sebanyak 34 responden (34\%), sedangkan sisanya sebanyak 18 orang (18\%) menyatakan sangat setuju terhadap keunggulan Biokos BOTU-LIKE.

\section{Alasan Menggunakan Produk (Bagi Pengguna)}

Dari hasil kuesioner, didapat 68 responden yang menggunakan produk Biokos BOTU-LIKE. Hasilnya, sebanyak 28 responden (41.2\%) menyatakan bahwa mereka menggunakan Biokos BOTU-LIKE karena ingin mencegah terjadinya kerutan pada kulit wajah mereka. Yang menggunakan Biokos BOTU-LIKE karena ingin menghilangkan kerutan berjumlah 26 responden (38.2\%) sedangkan sisanya sebanyak 14 responden (20.6\%) menyatakan mereka menggunakan karena tidak puas dengan produk yang digunakan sebelumnya. 


\section{Halangan Mengunakan Produk (Bagi Non-pengguna)}

Bagi non-pengguna Biokos BOTU-LIKE yang berjumlah 32 orang, mayoritas responden, yaitu 19 responden (59.4\%) menjawab bahwa mereka merasa belum membutuhkan produk perawatan untuk kerut wajah. Sebanyak 10 responden $(31.3 \%)$ menjawab bahwa halangan mereka tidak menggunakan Biokos BOTU-LIKE karena harganya yang mahal, sedangkan yang tidak menggunakan Biokos BOTU-LIKE karena sudah puas dengan produk yang mereka gunakan sebanyak 3 orang $(9.4 \%)$.

\section{Kepercayaan Biokos BOTU-LIKE Dapat Mengatasi Masalah Kerutan}

Sebanyak 55 responden percaya bahwa Biokos BOTU-LIKE dapat mengatasi masalah kerutan, 40 responden menjawab ragu-ragu, dan 5 responden menjawab tidak percaya.

\section{Pembelian}

\section{Keinginan Membeli Ulang (Bagi Pengguna)}

Dari 68 responden, sebanyak 39 responden $(57,4 \%)$ akan membeli ulang produk Biokos BOTU-LIKE, sebanyak 20 responden $(29,4 \%)$ akan menunda, dan sisanya 9 responden menyatakan tidak akan membeli lagi.

\section{Ketertarikan Membeli (Bagi Non-Pengguna)}

Bagi non-pengguna Biokos BOTU-LIKE ditanyakan mengenai ketertarikan mereka untuk membeli produk. Sebanyak 26 responden $(81,3 \%)$ menyatakan akan membeli untuk mencoba dan 6 responden menyatakan tidak akan mencoba untuk membeli produk Biokos.

\section{Penggunaan Pascapembelian dan Evaluasi Ulang Alternatif yang Dipilih Merekomendasikan Biokos BOTU-LIKE pada Orang Lain (Bagi Pengguna)}

Berdasarkan hasil survei, 68 responden yang menggunakan Biokos BOTU-LIKE 29 orang (42.6\%) menyatakan mereka akan menunda untuk merekomendasikan produk Biokos BOTU-LIKE pada orang lain, sebanyak 28 responden (41.2\%) menyatakan akan merekomendasikan produk pada orang lain, sedangkan sisanya, 11 responden $(16.2 \%)$ menyatakan mereka tidak akan merekomendasikan.

\section{Kesesuaian Kinerja dengan Harapan (Bagi Pengguna)}

Konsumen yang telah menggunakan produk Biokos BOTU-LIKE menyatakan bahwa kinerja Biokos BOTU-LIKE telah cukup sesuai dengan harapan mereka adalah sebanyak 34 responden (50\%), 20 responden (29.4\%) menyatakan bahwa kinerja Biokos BOTU-LIKE sesuai dengan harapan mereka. Sebanyak 14 responden (20.6\%) menyatakan Biokos BOTU-LIKE tidak sesuai dengan harapan mereka. 


\section{Tanggapan terhadap Kualitas (Bagi Pengguna)}

Konsumen pengguna Biokos BOTU-LIKE yang menyatakan kualitas produk sudah cukup baik sebanyak 32 responden (47.1\%), 28 orang (41.2\%) menyatakan kualitas produk Biokos BOTU-LIKE baik, sisanya sebanyak 8 responden (11.8\%) merasa kualitas Biokos BOTU-LIKE tidak baik.

\section{Tanggapan terhadap Harga}

Para pengguna Biokos BOTU-LIKE Series menyatakan bahwa harga produk sebesar Rp 94.500 untuk day cream dan night cream, dan sebesar Rp124.500,00 untuk serum sudah sesuai. Hal itu dapat dilihat sebagian besar konsumen, yaitu sebanyak 30 responden $(44.1 \%)$ yang menyatakan harganya sesuai sedangkan sebanyak 24 orang (35.3\%) lainnya menyatakan Biokos BOTU-LIKE mahal. Hanya 14 responden (20.6\%) yang menyatakan produk Biokos BOTU-LIKE murah.

\section{Tanggapan terhadap Komposisi}

Mayoritas responden sebanyak 39 orang (57.4\%) menyatakan setuju bahwa komposisi Biokos BOTU-LIKE Series aman digunakan. Sebanyak 22 responden menyatakan sangat setuju bahwa Biokos BOTU-LIKE Series aman digunakan. Sisanya, sebanyak 7 orang menyatakan tidak setuju bahwa komposisi yang terkandung dalam Biokos BOTU-LIKE Series aman digunakan.

\section{PENUTUP}

Untuk bauran pemasaran produk, PT Martina Berto menerapkan bauran produk dengan menghasilkan tiga jenis produk BOTU-LIKE Series, yaitu Anti Wrinkle Intensive Correcting Serum, Anti Wrinkle Protective Day Treatment, dan Anti Wrinkle Overnight Treatment. Kemasan berwarna hijau untuk mendukung citra produk sebagai produk untuk mengatasi kerutan kulit yang komposisinya dari bahan alami. Harga yang ditetapkan PT Martina Berto sebesar Rp94,500,00 dan Rp124,500,00. Untuk mempromosikan Biokos BOTU-LIKE Series, PT Martina Berto mengadakan berbagai kegiatan, seperti Launch Gathering, periklanan di koran Kompas, Majalah, roadshow ke kota besar, Festival, kemasan limited edition, hadiah, dan diskon harga. PT Martina Berto menerapkan saluran dua tingkat untuk memasarkan produk Biokos BOTU-LIKE dan bekerja sama dengan PT Sari Ayu Indonesia untuk mendistribusikan produk ke outlet milik PT Martha Tilaar, toko kosmetik, dan departemen store.

Berdasarkan penerapan bauran pemasaran yang telah dibahas, dapat disimpulkan bahwa bauran pemasaran yang dilakukan PT Martina Berto sudah baik. Hal itu ditunjukkan besarnya jumlah permintaan awal terhadap produk yang melebihi target penjualan awal produk Biokos BOTU-LIKE Series sebesar 3 kali lipat (www.swa.co.id). 
Preferensi seluruh konsumen (tingkat agregat) menyatakan bahwa kombinasi level atribut Biokos BOTU-LIKE yang paling disukai adalah harga produk pada level Rp94.500,00 dan manfaat produk untuk mengencangkan dan melembabkan kulit. Untuk atribut komposisi, level atribut yang disukai adalah bahan anti alergi dan anti iritasi.

Berdasarkan perilaku pengambilan keputusan pembelian, dari 100 responden, terdapat 68 orang pengguna Biokos BOTU-LIKE Series, sebanyak 39 responden $(57,4 \%)$ menyatakan akan membeli ulang dan 28 orang menyatakan akan merekomendasikan produk pada orang lain. Tanggapan konsumen yang telah menggunakan produk Biokos BOTU-LIKE Series dinilai secara keseluruhan cukup baik dan kinerja produk Biokos BOTU-LIKE dinilai telah cukup sesuai dengan harapan konsumen. Kualitas produk yang dinyatakan oleh 60 konsumen dinilai cukup baik dan sebanyak 30 orang konsumen menyatakan harga yang ditawarkan pada ketiga jenis produk Biokos BOTU-LIKE telah sesuai dengan manfaatnya. Di samping itu, terdapat 61 konsumen yang setuju bahwa komposisi produk Biokos BOTU-LIKE aman digunakan untuk kulit. Tanggapan terhadap faktor tersebut yang menjadi indikator bahwa konsumen merasa puas terhadap kinerja produk.

Saran berdasarkan penelitian adalah PT Martina Berto sebaiknya menetapkan harga yang lebih rendah untuk produk Anti Wrinkle Intensive Correcting serum agar konsumen tertarik untuk membeli produk serum yang merupakan produk inti dari Biokos BOTU-LIKE Series. PT Martina Berto sebaiknya lebih banyak melakukan kegiatan edukasi pasar mengenai manfaat BOTU-LIKE Series dan keunggulan BOTU-LIKE Series yang kinerjanya mirip suntik botox namun aman bagi kulit. PT Martina Berto sebaiknya memperbanyak promosi Produk Biokos BOTU-LIKE Series melalui iklan media agar masyarakat dapat lebih mengenal produk dan merangsang perilaku pembelian.

\section{DAFTAR PUSTAKA}

Anwar, Adrian, Eric Rinaldo Syah, dan Mori Prananto. 2004. Building A Better Shopping Experience to Increase Consumers Satisfaction through the Fullfilment of Consumers Value Perceived. Tesis Magister Management Information System Universitas Bina Nusantara, Jakarta.

Alma, Buchari. 2004. Manajemen dan Pemasaran Jasa. Edisi Revisi. Bandung: CV Alfabeta.

Churchill, JR, Gilbert A., and Dawn Lacobbuci. 2005. Marketing Research: Methodological Foundations. Ninth Edition. Thomson, South-Western.

Cooper, Donald R. and Pamela S. Schindler. 2006. Business Research Methods. Ninth Edition. New York: McGraw Hill. 
Hair, JR, Joseph F., Ralph E. Anderson, Ronald L. Tatham, and William C. Black. 1998. Multivariate Data Analysis. Fifth Edition. New Jersey: Prentice Hall International, Inc.

Hawkins, Del I, Roger J. Best, and Kenneth A. Coney. 2001. Consumer Behavior: Building Marketing Strategy. Eight Edition. New York: McGraw Hill.

Khotijah, Siti. 2004. Smart Strategy of Marketing Persaingan Pasar Global. Bandung: CV Alfabeta.

Kotler, Philip. 2004. Manajemen Pemasaran Edisi Milenium. Jilid-1. Jakarta: PT INDEKS.

Kotler, Philip and Gary Armstrong. 2001a. Prinsip-Prinsip Pemasaran. Jilid-1. Jakarta: Erlangga.

Kotler, Philip and Gary Armstrong. 2001b. Prinsip-Prinsip Pemasaran. Jilid-2. Jakarta: Erlangga.

Peter, Paul J. and Jerry C. Olson. 2000. Perilaku Konsumen dan Strategi Pemasaran. Jilid-1. Jakarta: Erlangga.

Schiffman, Leon G. and Leslie Lazar Kanuk. 2004. Consumer Behavior. $8^{\text {th }}$ Edition. New Jersey: Prentice Hall International, Inc.

Sekaran, Uma. 2003. Research Methods for Business: A Skill Building Approach. Fourth Edition. New York: John Wiley \& Sons, Inc.

Sugiyono. 2006. Metode Penelitian Bisnis. Cetakan kesembilan. Bandung: CV Alfabeta.

Sumarwan, Ujang. 2004. Perilaku Konsumen: Teori dan Penerapannya dalam Pemasaran. Bogor: PT Ghalia Indonesia.

Supranto, J. 2004. Analisis Multivariat Arti dan Interpretasi. Jakarta: PT Rineka Cipta.

Ulrich, Karl T. and Steven D. Eppinger. 2003. Product Design and Development. Third Edition. New York: McGraw Hill.

Umar, Husein. 2003. Metode Riset Perilaku Konsumen Jasa. Jakarta: PT Ghalia Indonesia.

http://www.marthatilaar.com/

http://www-rohan.sdsu.edu/

http://www.sawtoothsoftware.com/

http://www.en.wikipedia.com 